\title{
Some Therapeutic Aspects in Pediatric Hydrocephalus
}

\author{
Manuel Castro-Grago*, David Dacruz-Álvarez and Laura Pérez-Gay \\ Department of Pediatrics, University of Santiago de Compostela, Spain
}

Submission: October 24, 2017; Published: March 19, 2018

*Corresponding author: M Castro-Gago, Department of Pediatrics, University Hospital, School of Medicine, University of Santiago de Compostela, Spain, Tel: + 34-981-951121; Fax: + 34981 531987; E-mail: manuel.castro.gago@usc.es

Abstract

We carry out a review about some therapeutic aspects of childhood hydrocephalus. This description has been divided into the following groups: surgical treatment, pharmacological treatment, and spontaneous improvement based on self-compensated criteria: cerebrospinal fluid dynamics, clinical and radiological, cerebrospinal biochemical, and hemodinamical parameters. We conclude with some reflections about its prognosis.

Keywords: Acetazolamide; CSF absorption; CSF pressure; Hydrocephalus; Neuroendoscopic; oxypurines; Shunt; Transcranial Doppler

Introduction

Table 1: Diagnostic test in hydrocephalus

\begin{tabular}{|c|}
\hline Cranial circumference measurements \\
\hline Transcranial illumination \\
\hline Eye examination-papilla \\
\hline Prenatal infections testing \\
\hline Electroencephalography \\
\hline Cranial X-Ray \\
\hline $\begin{array}{c}\text { Neuroradiology: Transfontanelar ulrasound; CT head (Computed axial } \\
\text { tomography); MRI of the brain; MRI-angiography; brain Angiography }\end{array}$ \\
\hline CSF pressure registration \\
\hline CSF dynamics and reabsorption (isotopic cisternography) \\
\hline CSF oxipurines level (HPLC) \\
\hline Cerebral blood flow (Doppler) \\
\hline
\end{tabular}

Hydrocephalus represents a relatively common chapter in pediatric neurology pathology, specially, during the neonatal and infant period. This critical time for brain maturation makes early diagnosis and optimal therapy a real need to prevent severe and permanent consequences [1]. Nowadays, its etiological, pathogenic and functional diagnosis is easy and safe. It is based on anamnesis and clinical data at first and confirmed by specific diagnostic test (Table 1) [2-6]. Transcranial illumination, a classical and simple test, feasible anywhere you work, can sometimes inform about the degree of ventricular dilatation or even the type of fluid collection (arachnoid or porencephalic cysts, cystic dilatation of the fourth ventricle "Dandy-Walker syndrome", etc). Transcranial ultrasound usually allows diagnosis and follows up in the newborn and infant patient. It is critical to make the differential diagnosis with other entities presenting with macrocephaly, especially benign subdural effusion or benign external hydrocephalus, which occurs during infancy and includes macrocephaly associated to frontal, parietal and temporal subarachnoid space dilatation and normal ventricular size, evolving with spontaneous resolution over time $[5,7]$.

\section{Treatment}

\section{Surgical management}

Surgical pediatric hydrocephalus management has progressed including many techniques, ranging from

choroid plexus coagulation, translaminar ventriculostomy, Torkildsen and plexectomy to cerebrospinal fluid (CSF) shunt devices [2-5]. The treatment advocated sixty years ago is still valid and is probably the most effective treatment in most of the children with noncompensated hydrocephalus: to place a shunt $[2-5,8,9]$. However, it is not free of complications, some of them severe. (Table 2) [2-5,10-12]. Today, most noncompensated hydrocephalic patients must be placed on a ventriculoperitoneal shunt, remembering that if it is working by pressure gradient it is necessary to adjust its opening pressure to intraventricular CSF pressure [13]. If tumor or every space-occupying lesion is 
the etiology, hydrocephalus can be solved by surgery of the mass, but sometimes a valve will be need in addition [3,4]. In DandyWalker Syndrome surgical opening the roof of fourth ventricle to the cistern magna can be the treatment. A double system or two intracranial catheter linked in "Y" can be used when for example, there is a non surgical cyst not draining to ventricular system $[3,4]$.

Table 2: Shunts complications, only in ventriculo-atrial shunt.

\begin{tabular}{|c|c|}
\hline \multirow{5}{*}{ Early complications } & Surgery mortality \\
\hline & CSF leak \\
\hline & Insufficient drainage \\
\hline & Infections \\
\hline & Subdural hemorrhage \\
\hline \multirow{12}{*}{ Delayed complications } & $\begin{array}{l}\text { The effect of child growth over } \\
\text { the shunt }\end{array}$ \\
\hline & Thromboembolism* \\
\hline & Infections \\
\hline & Shunt nephritis* \\
\hline & Seizures \\
\hline & Microcephaly \\
\hline & Craniosynostosis \\
\hline & Ventricular catheter blockage \\
\hline & Cardiac perforation* \\
\hline & Overdrainage \\
\hline & Distal catheter obstruction \\
\hline & Slit-ventricle syndrome \\
\hline \multirow{9}{*}{ Abdominal complicationss } & Detachment of distal catheter \\
\hline & Ascites \\
\hline & Intestinal perforation \\
\hline & Abdominal distension \\
\hline & Intestinal obstruction \\
\hline & Peritoneal cyst \\
\hline & Catheter externalization \\
\hline & Hydrocele/hernia \\
\hline & Pneumoencephalus \\
\hline
\end{tabular}

Repetitive ("daily") lumbar puncture is considered the initial therapy for newborn hydrocephalus due to ventricular bleeding. It removes blood and proteins from CSF and improves intracranial hypertension. Efficacy of this method has been questioned and controversy exists. The indication would be when ventricular dilatation (ultrasound controlled) is evolving slowly. If it is fast, an external ventricular drain, "ventriculostomy", is the first option and if it is ineffective, to place a shunt. [2-5,9,14]. Debated alternatives are lumbar puncture associated to drugs affecting CSF production and/or absorption and the use of intraventricular fibrinolytic treatment ("tissue plasminogen activator") combined with drain and ventricular irrigation [14]. Endoscopic neurosurgery has appeared over the last years to treat obstructive hydrocephalus and those with multiple septums in children and teenagers. It is less effective for toddlers and infants [3,4, 15-18].

\section{Drug treatment}

There are drugs decreasing CSF production, such us acetazolamide and isosorbide. This one also acts increasing its re absorption but it is contraindicated in newborn because of adverse effects. Its efficacy is considered if hydrocephalus is near self compensation because if cerebral mantle thickness is less than $15 \mathrm{~mm}$ resolution with this therapy is uncommon. The main indication is in temporal control of hydrocephalus when a CNS infection exists or in case of high CSF protein concentration, when a shunt is temporally contraindicated [1-4,9]. Therapeutic strategy would be acetazolamide $(25-100 \mathrm{mg} / \mathrm{kg} /$ day $)$ associated to furosemide $(1 \mathrm{mg} / \mathrm{kg} /$ day). This combination is not free of adverse effects, such as renal damage ("nephrocalcinosis") or severe neurological consequences, when treating ventricular dilatation after preterm intracranial bleeding [19].

\section{Expectant management: "self-compensation criteria"}

Some children with communicating hydrocephalus progress with a self compensation, so not always a shunt is the first option. Those children have a progressive slowing in cranial perimeter growth until they reach a normal percentile or above maximum percentile but growing in parallel. The ventricular dilatation doesn't progress and the psychomotor development is normal. In the past, Hagberg and Naglo [20] justified a hands-off management during the first months of life only if no regression nor neurological disturbances were observed, no increase in the ventricular dilatation and when cranial circumference is going to normal percentile. Zachary [21], studying hydrocephalus in spinal dysraphism, used the CSF pressure and cerebral mantle thickness as a guide. When cerebral mantle thickness was more than $35 \mathrm{~mm}$ y and CSF pressure less than $300 \mathrm{~mm} 3$ he waited. The important thing is when to apply this option at diagnosis, in this sense we elaborated in the last thirty-seven years several criteria of self-compensating communicating hydrocephalus based on CSF dynamics, clinical and radiological, CSF biochemical, and hemodinamical parameters.

a) CSF dynamics criteria: they consider CSF pressure and re absorption combination, evaluated by radio-isotope cisternography. If a child with communicating hydrocephalus has CSF pressure and reabsorption in normal values it is probably progressing to self compensation, while if one or both parameters are incorrect, it is not [22].

b) Clinical and neuroimaging criteria: mean weekly increase in cranial circumference combined with Evans' index ("ratio of maximum width of the frontal horns to the maximum width of the inner table of the cranium"). So if the mean weekly increase is equal or less than $0.4 \mathrm{~cm}$ and Evans index equal or less than 0.5 , it will probably progress to self compensation [23].

c) Biochemical criteria: Xanthine and hypoxanthine level in CSF increase in case of neuronal hypoxia or ischemia. Tissue hypoxia is a known cause of adenine nucleotide 
depletion and its intermediate metabolites appearance in extracellular matrix and corporal fluids. They are used as metabolic markers of ATP depletion [24,25]. This energy deficiency in hydrocephalus could be related to several factors (interrelated as well) such as increase in intracranial pressure, CSF dynamics alteration, decrease in brain blood flow, periventricular edema, [26,27]. The oxipurines "hypoxanthine and xanthine" are the last product of ATP degradation, just before uric acid formation. Hypoxanthine is also the substrate in the recovery of purine nucleotides through hypoxanthineguanine-phosphoribosyltransferase (HGPRT) enzyme $[24,25]$. CSF oxipurines usually rise when hydrocephalus is not compensated [26,27]. If both purinic metabolites are in the normal CSF range (hypoxanthine $=5.94 \pm 0.74$, xanthine $=5.20 \pm 0.87$ ) then hydrocephalus is self compensated but if they rise it will be necessary to place a shunt (Table 3). These metabolites are also useful to know evolution of the hydrocephalus after 15 day of placing the shunt (Table 4) $[28,29]$. When shunt dysfunction is suspected, it could be confirmed measuring CSF hypoxanthine and xanthine because they rise in this clinical situation [30].

Table 3: CSF Xanthine, hypoxanthine and total oxipurines level ( $\mathrm{nmol} / \mathrm{L}$ ) in pediatric hydrocephalus and normalcontrol. Differences between non compensated and other two groups are statistically significative $(p<0.001)$ Castro-Gago and Rodríguez et al. [29].

\begin{tabular}{|c|c|c|c|c|}
\hline Group & (n) & Xanthine & Hypoxanthine & $\begin{array}{c}\text { Total } \\
\text { oxipurines }\end{array}$ \\
\hline Control & $(8)$ & $5.20 \pm 0.87$ & $5.94 \pm 0.74$ & $11.29 \pm 1.11$ \\
\hline $\begin{array}{c}\text { Self- } \\
\text { compensated }\end{array}$ & $(13)$ & $5.17 \pm 1.53$ & $5.71 \pm 1.72$ & $10.79 \pm 3.02$ \\
\hline $\begin{array}{c}\text { Non } \\
\text { compensated }\end{array}$ & $(15)$ & $9.90 \pm 2.44$ & $9.91 \pm 1.90$ & $19.82 \pm 4.14$ \\
\hline
\end{tabular}

Table 4: CSF oxipurines level ( $\mathrm{nmol} / \mathrm{L})$ in non compensated hydrocephalus, before and after shunt Differences are statistically significant $(p<0.001)$ Castro-Gago et al. [29].

\begin{tabular}{|c|c|c|c|}
\hline & Xanthine & Hypoxanthine & $\begin{array}{c}\text { Total } \\
\text { oxipurines }\end{array}$ \\
\hline Pre-shunt & $9.90 \pm 2.44$ & $9.91 \pm 1.90$ & $19.82 \pm 4.14$ \\
\hline After-shunt & $4.22 \pm 1.76$ & $4.67 \pm 1.36$ & $8.80 \pm 2.69$ \\
\hline
\end{tabular}

d) Hemodynamic criteria: It is based on brain blood flow values calculated with transcranial Doppler in middle cerebral artery (systolic velocity, mean flow velocity, Gosling pulsatility index, Pourcelot resistance index) [31]. If these parameters are normal it is probably that hydrocephalus is self compensated and if not, a shunt is needed [32]. This criterion is also used to know how hydrocephalus progresses and for diagnosis of shunt malfunction [32].

In conclusion there is a narrow relation between the four criteria and statistical significance is similar for everyone $[22,23,28,29,32]$, so the most practical criteria is the last one (transcranial Doppler) because it is a non invasive technique, well tolerated, affordable, feasible, with real time results, and can be repeated when needed.

\section{Prognosis}

In general, when a child is diagnosed of hydrocephalus and properly treated, his prognosis is good (exceptions exist) but it is needed periodic control of neurological status and if placed, shunt functionality $[3,5,33]$. Some children with hydrocephalus had significantly impaired learning, memory and executive functions [34]. If self compensation is achieved the prognosis is better than those requiring a shunt $[3,5]$. In the recent past, some authors believe that intellectual quotient is less likely affected, even in great hydrocephalus [35-38]. However, other authors observed that there is a correlation between cerebral mantle thickness or brain volume at diagnosis and their psychomotor future. If cerebral mantle thickness is less than $2 \mathrm{~cm}$ or brain volume is less than $60 \%$ psychomotor progression may not be achieved as normal, apart from etiology [3,5,39-42].

\section{References}

1. Castro-Gago M (1982) Hydrocephalus during neonatal period. In: Fernández-ÁE (Ed.), Book of the first national neuropediatric congress, neuropediatric Spanish society, Barcelona, Spain, pp. 197-216.

2. Castro-Gago M (1990) Childhood Hydrocephalus management. In: Nieto BM(Ed.), Book of the Third neuropediatric national congress, neuropediatric Spanish society, Sevilla, Spain, pp. 241-247.

3. Castro-Gago M (1999) Treatment of neurological illness in children and teenagers, Espaxs, Barcelona, Spain, pp 99-103.

4. Garton HJ, Piatt JH (2004) Hydrocephalus. Pediatr Clin North Am 51(2): 305-325.

5. Castro-Gago M, Gómez-Lado MC (2014) Central nervous system malformations. In: Moro M, Málaga S, Madero L (Eds.), Cruz Tratado de Pediatría. $\left(11^{\text {th }}\right.$ edn) Editorial médica panamericana, Madrid, Spain, pp. 2141-2149.

6. Melo JRT, Rocco DF, Blanot S, Cuttaree H, Sainte-Rose C, et al. (2011) Transcranial Doppler can predict intracranial hypertension in children with severe traumatic brain injuries. Childs Nerv Syst 27(6): 979-984.

7. Castro-Gago M, Pérez-Gómez C, Novo-Rodríguez MI, Blanco-Barca O, Alonso-Martín A, et al. (2005) Benign idiopathic external hydrocephalus (benign subdural collection) in 39 children: its natural history and relation to familial macrocephaly. Rev Neurol 40(9): 513-517.

8. Raimondi AJ (1988) Shunts, indications, problems and characteristics. Childs Nerv Syst 4 (6): 321-324.

9. Rekate HL (1994) Treatment of hydrocephalus. In: Cheek WR (Ed.), Pediatric neurosurgery. Surgery of the developing nervous system. ( $3^{\text {rd }}$ edn), Saunders WB, Philadelphia, USA, pp. 202-220.

10. Guertin SR (1987) Cerebrospinal fluid shunts. Evaluation, compliactions and crisis management. Pediatr Clin North Am 34(1): 203-217.

11. Epstein F, Lapras C, Wisoff JH (1988) Slit-ventricle syndrome: Etiology and treatment. Pediatr Neurosci 14(1): 5-10.

12. Marlin AE, Gaskill SJ (1994) Cerebrospinal fluid shunts: complications and results. In: Cheek WR (Ed.), Pediatric neurosurgery. Surgery of the developing nervous system. ( $3^{\text {rd }}$ edn), Saunders WB, Philadelphia, USA, pp. 221-233.

13. Castro-Gago M, Allut AG, Pavón P, Fraga JM, Pombo M, et al. (1981) CSF pressure as type of shunt device criteria in non tumoral pediatric hydrocephalus. Rev Esp Pediatr 37(3-4): 209-214.

14. Pulido-Rivas P, Martínez-Sarries FJ, Ochoa M, Sola RG (2007) Treatment of hydrocephalus secondary to intraventricular haemorrhage in preterm infants. Rev Neurol 44(10): 616-624. 
15. Jiménez-León JC (1997) Neuroendoscopy: diagnosis and therapeutic uses. Rev Neurol 25(142): 941-945.

16. Jiménez-León JC, Jiménez-Betancourt CS (2003) Indications for neuro endoscopy. Rev Neurol 36 (3): 274-281.

17. Cinalli G, Maixner WJ, Sainte-Rose C (2004) Pediatric hydrocephalus. Springer-Verlag, Milan, Italy, pp. 361-388.

18. Sandberg DI (2008) Endoscopic management of hydrocephalus in pediatric patients: a review of indications, techniques, and outcomes. J Child Neurol 23(5): 550-560.

19. International PHVD Drug Trial Group (1998) International randomized controlled trial of acetazolamide and furosemide in post haemorrhage ventricular dilatation in infancy. Lancet 352(9126): 433-440.

20. Hagberg B, Naglo AS (1972) The conservative management of infantile hydrocephalus. Acta Paediatr Scand 61(2): 165-677.

21. Zachary RB (1971) Recent advances in the management of myelomeningocele. In: Riuchard PP, Hecker N, Prevot J (Eds.), Acquisitions in pediatric surgery. Masson et Cie, París, France, pp. 155170.

22. Castro-Gago M, Tato F, Martínez RR, Pavón P, Fraga JM (1980) Non tumoral hydrocephalus during childhood. CSF dynamics study importance for diagnosis and therapy. Rev Esp Pediatr 36(1): 61-74.

23. Castro-Gago M, Novo I, Ugarte J, Pombo M, Tojo R, et al (1986) Self compensation criteria in pediatric hydrocephalus. Rev Esp Pediatr 42(3): 237-342.

24. Castro-Gago M, Rodríguez-Nuñez A, Novo-Rodríguez MI, Eirís-Puñal $J(2001)$ Biochemical parameter predictive of neuronal damage in childhood. Rev Neurol 32 (12): 1141-1150.

25. Castro-Gago M, Rodríguez-Nuñez A (2001) Biochemical signs for prediction of deficiencies in the newborn and children. In: Sinha KK, Chandra P (Eds). Advances in Clinical Neurosciences. The Catholic Press, Jharkhand, India, pp. 423-444.

26. Bejar R, Saugstad OD, James H, Gluck L (1983) Increased hypoxanthine concentrations in cerebrospinal fluid of infants with hydrocephalus. J Pediatr 103(1): 44-48.

27. Levin SD, Brown JK, Harkness RA (1984) Cerebrospinal fluid hypoxanthine and xanthine concentrations as indicators of metabolic damage due to raised intracranial pressure in hydrocephalic children. J Neurol Neurosurg Psychiatry 47(7): 730-733.

28. Castro-Gago M, Lojo S, Del Río R, Rodríguez A, Novo I, et al. (1986) The concentrations of xanthine and hypoxanthine in cerebrospinal fluid as therapeutic guides in hydrocephalus. Childs Nerv Syst 2(3): 109-111.
29. Castro-Gago M, Rodríguez IN, Rodríguez-Nuñez A, Guitian JP, Rocamonde SL, et al. (1989) Therapeutic criteria in hydrocephalic children. Childs Nerv Syst 5(6): 361-363.

30. Castro-Gago M, Rodríguez-Segade S, Camiña F, Bollar A, RodríguezNuñez A (1993) Indicators of hypoxia in cerebrospinal fluid of hydrocephalic children with suspected shunt malfunction. Childs Nerv Syst 9(5): 275-277.

31. Galarza M, Lazareff JA (2004) Transcranial Doppler in infantile cerebrospinal fluid disorders: clinical validity. Neurol Res 26(4): 409413.

32. Rodríguez-Nuñez A, Somoza-Martín M, Gómez-Lado C, Eirís-Puñal J, Camiña-Darriba F, et al. (2008) Therapeutic criteria in communicating childhood hydrocephalus. J Neurosurg Sci 52(1): 17-21.

33. Lindquist B, Persson EK, Fernell E, Uvebrant P (2011) Very longterm follow-up of cognitive function in adults treated in infancy for hydrocephalus. Childs Nerv Syst 27(4): 597-601.

34. Lindquist B, Persson EK, Uvebrant P, Carlsson G (2008) Learning, memory and executive functions in children with hydrocephalus. Acta Paediatr 97(5): 596-601.

35. Bottcher J, Jacobsen S, Gydented C, Harmsen A, Gloenselt-Trap B (1978) Intellectual development and brain size in 13 shunted hydrocephalic children. Neuropädiatrie 9(4): 369-377.

36. Hagberg B (1962) The sequeles of spontaneously arrested infantile hydrocephalus. Dev Med Child Neurol 4(12): 583-587.

37. Raimondi AJ, Soare P (1974) Intellectual development in shunted hydrocephalic children. Am J Dis Child 127(5): 664-671.

38. Billard C, Santini JJ, Gillet P, Nargeot MC, Adrien JL (1985-1986) Long term intellectual prognosis of hydrocephalus with reference to 77 children. Pediatr Neurosci 12(4-5): 219-225.

39. Foltz EL, Shurtleff DB (1963) Five year comparative study of hydrocephalus in children with and without operation (113 cases). J Neurosurg 20(12): 1064-1079.

40. Young HF, Nulsen FE, Weiss MH, Thomas P (1973) The relationship of intelligence and cerebral mantle in treated infantile hydrocephalus. (IQ potential in hydrocephalic children). Pediatrics 52(1): 38-44.

41. Shurtleff DB, Foltz EL, Loeser JD (1973) Hydrocephalus: A definition of its progresion and relationship to intellectual function, diagnosis and complications. Am J Dis Child 125(5): 688-693.

42. Castro-Gago M, Iglesias Diz JL, Villanueva MC, Esquete C, Peña J (1981) Psychomotor development in non tumoral pediatric hydrocephalus. Its relationship with cerebral mantle thickness. Rev Esp Pediatr 37(1): 27-30.

\section{Your next submission with Juniper Publishers will reach you the below assets}

- Quality Editorial service

- Swift Peer Review

- Reprints availability

- E-prints Service

- Manuscript Podcast for convenient understanding

- Global attainment for your research

- Manuscript accessibility in different formats

( Pdf, E-pub, Full Text, Audio)

- Unceasing customer service

Track the below URL for one-step submission https://juniperpublishers.com/online-submission.php 